(C) 2020 Kurysh. This article is distributed under the terms of CC Attribution-Share Alike 4.0 International as described at https://creativecommons.org/licenses/ by-sa/4.0

UDC: 378.015 .3

\title{
METHODOLOGY ASPECTS OF SCIENCE TEACHERS' ENTREPRENEURIAL COMPETENCY DEVELOPMENT: EUROPEAN AND UKRAINIAN PERSPECTIVE
}

\author{
Natalia Kurysh, \\ Deputy Director for Academic Affairs \\ Chernivtsi In-Service Teacher Training Institute, Chernivtsi, Ukraine \\ https://orcid.org//0000-0001-5864-8502; e-mail:kurish.natalya@ukr.net
}

The methodical aspects of the formation of entrepreneurial competence of teachers of Science teachers in the institutions of in-service teacher education are defined in the article. The analysis of theoretical views of Ukrainian and European scientists to the definition of critical concepts are held: "teaching methods", "traditional methods", "interactive methods", "blended learning", "project method".

Based on the conducted diagnostic the level of awareness of Science teachers related to the development of the entrepreneurship key competency is identified, and educational process of the institutions of in-service teacher education is updated by disseminating the European experience.

Methodological bases of teacher training in European educational environment are revealed, and national perspectives, which are based on the principles of variability and interrelation of traditional and interactive methods, which provide the formation of entrepreneurship competency of Science teachers in the system of inservice teacher education are justified.

The practical orientation of the use of interactive methods in the professional training of teachers is substantiated, which contributes to the positive dynamics of the formation of entrepreneurial competence of Science teachers.

Key words: teaching methods, traditional methods, interactive methods, blended learning, project method.

У статті визначено методичні аспекти формування підприемницъкої компетентності вчителіВ природничих спеціальностей у закладах післядипломної педагогічної освіти. Проведено аналіз теоретичних поглядіЪ, як украйнських так $і$ зарубіжних науковиів до визначення ключових понять: «методи навчання», «традиційні методи», «інтерактивні методи», «змімане навчання», «метод проектів».

На основі проведеної діагностики визначено рівень обізнаності вчителів природничих спечіальностей щодо розуміння ключової компетентності під- 
приємливість та модернізовано освітній процес украӥнсъких закладів післядипломної педагогічної освіти дисемінуючи європейсъкий досвід.

Розкрито окремі аспекти прочесу професійної підготовки педагогів у європейсъкому освітнъому просторі та визначено вітчизняні перспективи формування підприємницької компетентності вчителів природничих спеціальностей. Охарактеризовано організацію освітнъого прочесу закладів післядипломної освіти вчителів на приниипах варіативності та взаємозв'язку традиційних й інтерактивних методів навчання дорослих.

Обгрунтовано практичну спрямованість використання інтерактивних методів у професійній підготовиі педагогів, що сприяе позитивній динаміці сфрормованості підприємницької компетентності виителів природничих спеціальностей.

Ключові слова методи навчання, традиційні методи, інтерактивні методи, змішане навчання, метод проектів.

Introduction. Formation of entrepreneurial competence of Science teachers requires updating methodological approaches to the organization of the educational process of the institutions of in-service teacher education, which is based on the principles of variability and interconnection of traditional and interactive methods and is the key to institution development and quality of education.

Interactive teaching methods, in contrast to traditional ones, have several features, among which are the active interaction of participants of the educational process. In their study, Spencer Kagan, G. Lawrence Zane, Keith Widaman, F. Joseph Black Forest and Gary Tyrrell note that the use of collaborative learning methods increases the effectiveness of the learning process compared to traditional learning (Kagan, Zahn, Widaman, Schwarzwald \& Tyrrell, 1985). Ukrainian scientists A. Nisimchuk, O. Padalka, O. Shpak, in this case, understand interaction as "a relationship between people when they are in the process of solving common problems, influencing each other and complementing each other, successfully solve these problems." Herewith "there are changes in each of these entities, and in those objects to which the interaction is directed." (Nisimchuk, 2000).

$\mathrm{V}$. Kremen considers the method of teaching as "multifaceted, multidimensional, multi-quality, multifunctional didactic phenomenon" (Kremen, 2003), so quite naturally, there are various interpretations of it. M. Fitsula notes that teaching methods in higher education are significantly different from teaching methods in general secondary education. They are closer to the methods of science itself, because it presents not only scientific facts, but also reveals the methodology and methods of science itself (Fitsula, 2006).

In the institutions of in-service teacher education, similarly, teaching methods are mostly understood as "a way of orderly interrelated activities of teachers and students aimed at achieving the goals set by higher education" (Fitsula, 2006).

The purpose of the article is to determine the methodological aspects of the formation of Science teachers' entrepreneurial competency in the system of in-service teacher education.

The following tasks were set to ensure the implementation of this goal: 
1) to diagnose the formation of entrepreneurial competency of Science teachers during the professional training of teachers;

2) to determine the main aspects of the introduction of interactive teaching methods in the institutions of in-service teacher education based on a European perspective;

3) to analyze the results of the introduction of interactive teaching methods in the educational process of the institutions of in-service teacher education.

Methods. The institutions of in-service teacher education in the context of reforming the educational sector provide training for teachers to work in the New Ukrainian School and are looking for new approaches to the organization of the educational process. Conducting an experimental pedagogical study "Formation of readiness of Science teachers in the system of in-service teacher education for the development of entrepreneurial competency of high school students" based on the institutions of in-service teacher education provides an opportunity to update the methodological component of teacher training. 211 Science teachers were involved in the pedagogical research (108 in the experimental group and 203 in the control group).

During the research the following methods were used: theoretical for development of methodological bases and determination the possibility of further implementation of the obtained results; empirical (questionnaires, observations, surveys, situational exercises) were used to implement the initial and final diagnosis of the formation of entrepreneurial competency of Science teachers and readiness to implement interactive methods for teaching high school students; experimental were used to test the variability and interrelation of traditional and interactive methods for training teachers of Natural Sciences in the system of postgraduate pedagogical education for the development of entrepreneurial competency.

Main Text. Methodical teacher training is not a one-time act or a short-term phenomenon. This systematic and long-term work covers the whole cycle of the formation of skills of critical competency "entrepreneurship" of Science teachers through the search for ways of technological interaction of familiar and new in the teacher, modernization of existing personal potential, interrelated traditional and interactive methods (Grishina, 2003)

To conduct the diagnosis, a Questionnaire of determination of the level of awareness of Science teachers of understanding entrepreneurial competency, where the cognitive motive is dominated that characterizes the subject with interest in the results of their activities, knowledge of the conceptual apparatus and methods of entrepreneurial competency. The questionnaire consisted of 12 questions, which defined three blocks of the awareness indicator on the formation of entrepreneurial competency: questions1-4 cover the possession of the regulatory framework; 5-8 questions determine the knowledge of the conceptual apparatus; questions 9-12 reveal aspects of mastering the method of interactive learning.

The general level of awareness of Science teachers of the development of crucial competence entrepreneurship is shown in Table 1.

Level of awareness of Science teachers on the development of critical 


\section{competencies entrepreneurship}

\begin{tabular}{|l|l|c|c|c|c|}
\hline \multirow{2}{*}{ № } & \multicolumn{1}{|c|}{ Indicators } & \multicolumn{3}{c|}{ Teacher awareness levels (\%) } \\
\cline { 3 - 6 } & high & sufficient & average & low \\
\hline 1. & $\begin{array}{l}\text { Ownership of the regulatory } \\
\text { framework }\end{array}$ & 22,4 & 25,6 & 32,8 & 19,2 \\
\hline 2. & $\begin{array}{l}\text { Knowledge of the conceptual } \\
\text { apparatus }\end{array}$ & 16,8 & 22,4 & 36,8 & 24,0 \\
\hline 3. & $\begin{array}{l}\text { Mastery of interactive } \\
\text { learning techniques }\end{array}$ & 19,3 & 27,1 & 35,9 & 17,7 \\
\hline \multicolumn{2}{|l|}{ The average } & $\mathbf{1 9 , 5}$ & $\mathbf{2 5 , 0}$ & $\mathbf{3 5 , 2}$ & $\mathbf{2 0 , 3}$ \\
\hline
\end{tabular}

Based on the results of the survey, it is determined that, nevertheless, a relatively large proportion of $35.2 \%$ and $20.3 \%$ of Science teachers are aware at the middle and low levels of the development of key competency entrepreneurship, thus outlining new challenges for in-service teacher education ensuring the professional growth of teachers by the requirements of the Concept of the New Ukrainian School, forming a readiness for the development of entrepreneurial competence.

During the pedagogical experiment for assessing the formation of entrepreneurial competency of readiness of Science teachers, we used the framework of entrepreneurial competence, also known as EntreComp, developed by the Joint Research Center (JRC) of the European Commission on behalf of the DirectorateGeneral of Social Affairs and Social Integration (DG EMPL). The development of a reference framework with descriptors of learning outcomes is one of the measures selected by the European Commission to support the development of entrepreneurial competency in the field of education and employment (Bacigalupo, Kampylis, Punie \& Van den Brande, 2016). During the training of Science teachers, the EntreComp model was used to form entrepreneurial competency in two main dimensions: three areas of competence ("Ideas and Opportunities", "Resources" and "Transformation in Action"), which directly reflect the definition of entrepreneurial competency as the ability to implement ideas in actions that generate value for others, not for them-selves; and fifteen competencies, five in each area, which together is components of entrepreneurship as a competency for all citizens.

In the course of the experimental study, an initial and final survey of Science teachers was conducted to identify the dynamics of self-assessment of key competencies "entrepreneurship" in all three areas, table 2. 
of Science teachers (in points)

\begin{tabular}{|c|c|c|c|c|c|}
\hline \multirow[t]{3}{*}{ № } & \multirow{3}{*}{$\begin{array}{c}\text { Areas of entrepreneurial } \\
\text { competence }\end{array}$} & \multicolumn{4}{|c|}{ Self-assessment of Science teachers (in points) } \\
\hline & & \multicolumn{2}{|c|}{ Forming stage } & \multicolumn{2}{|c|}{ Generalizing stage } \\
\hline & & $E G$ & $C G$ & $E G$ & $C G$ \\
\hline 1. & Ideas and opportunities & 2,8 & 2,8 & 3,9 & 3,0 \\
\hline 2. & Resource & 2,7 & 2,8 & 3,9 & 2,9 \\
\hline 3. & Transformation in action & 3,0 & 2,9 & 4,2 & 3,0 \\
\hline & The average & 2,8 & 2,8 & 4,0 & 3,0 \\
\hline
\end{tabular}

The survey was conducted in experimental and control groups at the formative and generalizing stages, which revealed a positive dynamic of growth of self-esteem of key competencies "entrepreneurship" of Science teachers. If at the formative stage in the two groups the average was 2.8 points, then at the generalized stage there is a significant increase in the average in the experimental group by 1.2 points and is 4.0 points, which is 6 times higher than the growth of this indicator in the control group 0.2 points and is 3.0 points.

Positive dynamics is observed in the experimental groups due to the renewal of the methodological orientation of the training process, based on the principles of variability and interrelation of traditional and interactive methods during the professional development of teachers in in-service teacher education.

Methods that have often been used in the learning process are lecture, storytelling, conversation, text review or discussion. They are considered traditional, proven teaching methods, and in some situations merely necessary (especially when we want to convey as much information as possible in a short time). However, frequent use of traditional methods leads to the fact that educational process becomes ineffective. In one lesson, it is recommended to use several methods that complement each other, increase attractiveness and create an opportunity for students to be active. A lecture, conversation or text review can be enhanced and improved by other interactive methods, using a variety of relevant teaching aids: mind maps, reproductions, presentations, videos.

The combination of traditional and interactive methods encourages teachers to be proactive, creative, active, sociable, responsible, predictable, and so on.

Let us consider in more detail the diversification of interactive teaching methods of in-service teacher education, which contribute to the formation of readiness of Science teachers to develop entrepreneurial competency of high school students based on the European perspective.

Methods of "blended" learning. These methods have overcome the dissemination process in European education and successfully took root in Ukrainian educational institutions. The essence of the method grounds on cooperative learning with the use of ICT in the training of Science teachers - models in the best way the needs of today's world. Students work in small teams in the classroom: one group performs a search task using information and communication technologies, which are placed mainly on the periphery of the audience, another - receives tasks and seeks answers in educational and scientific literature, another - discusses and graphs the results of their 
work, a separate group of students works on the task with the teacher. Upon completion, each group presents the results of the study.

Criterion poker A method of discussing problematic issues and making joint decisions. It is implemented in several stages using a tablet on which there are three activity fields: central -note the issue proposed for discussion; the second - contains six positions for cards, which can be a proposal to solve the problem and are placed according to criteria from the most important (first position) to less critical (sixth position); third - four cards on the edges of the tablet, where we place positions that are less important in solving a particular problem. The issue to be discussed should be controversial, and the issues being addressed should be clear to the participants.

Discussion of the issue begins in small groups, after which they are grouped into large groups and discuss a single decision on a particular issue and present it to other participants.

The use of this method makes it possible to involve all participants in the work in separate small and large groups, teaches to select arguments, persuade, explain their views, seek consensus at each stage.

SWOT-analysis The SWOT-analysis method is widely used to analyze a particular situation with the identification of strengths and weaknesses, opportunities and threats. It helps to conduct an internal and external analysis of the problem, to diagnose processes and structures and to predict the future state of affairs.

This method is used when the issue of training is related to reflection on the implementation of specific changes or if it is necessary to evaluate the decision.

The teaching of Science teachers in institutions of in-service teacher education SWOT-analysis can be used to develop a model of "Teacher readiness for the development of entrepreneurial competency of high school students", where teachers assess their strengths that contribute to the development of entrepreneurial competency; weaknesses that hinder; opportunities that the teacher does not use to the full extent and anticipates the threats that may arise in the implementation of this idea.

Each participant can ask another to conduct a SWOT analysis independently and can work in groups to jointly analyze the problem situation, or create four teams, each of which will work on one of the four questions of analysis.

It should be noted that the strengths and capabilities should show all the positive aspects. Weaknesses and threats draw attention to the negative aspects of the situation.

It is essential to find a balance between positive and negative arguments, which will help to avoid exaggerated optimism or pessimism. Arguments are sorted from most important to weakest. After the discussion, it is necessary to leave the most substantial arguments at the end.

Mental maps (mind maps) are one of the teaching methods proposed by Tony Buzan, a world-renowned authority in the field of creative thinking (Bobinskaya, Shiyan \& Tovkalo, 2014). The use of mental maps is to visually process the selected issue using pictures, symbols, signs, diagrams and slogans.

Mental maps help to make notes by summarizing lessons and activities and organizing learning material to remember. 
The method of mental maps should be used to define certain concepts or start a discussion of new material (topic, section, module). It is also recommended for use in situations where it is needed to think, remember, plan and create.

When developing a mental map to a specific text, it is proposed to identify in it the keywords that best convey the primary and secondary content, develop imagination, evoke associations. Nouns or verbs that are easy to supplement with nouns or adjectives that help direct thinking in the right direction are best for this. Buzan called such words "keys" or "hooks" because they are easily combined with others and provide an opportunity to remember the read text (Bobinskaya, Shiyan, Tovkalo, 2014). Graphically combining keywords with the central theme of the map helps to understand and memorize the necessary material quickly.

Project method The role of projects in the educational process is difficult to overestimate. The term "project" (from the Latin projection - thrown forward) means a prototype, an ideal image of a predictable or possible object or state; in some cases, it is a plan, an idea of some action (Prokopenko \& Evdokimov, 2006). Most scientists believe that the project is a manifestation of the creative activity of human consciousness, through which the cultural transition from non-being to being (Genisaretsky, 2001).

The primary purpose of the project method, according to experts in the field of pedagogy, is to stimulate the interest of students in the formulation of problems, which involves the possession of a certain amount of knowledge, and through project activities - to effectively solve these problems; formation of skills to practi-cally apply and transform the acquired new knowledge; development of reflex (in the terminology of J. Dewey) or critical thinking (Bezrukova, 1996; Matyash, \& Semenova, 2000; Pakhomova, 2005). It is through learning projects that students learn to apply knowledge in practice, work in a team on a specific task, present their results, seek information from various sources, compare and analyze, persuade and lead. Thanks to the project method, students form the so-called project thinking - the ability to outline the ultimate goal and the time to achieve it to see specific results and people who will help implement them, plan joint activities based on what steps are needed to achieve the goal.

In the system of in-service teacher education, we offer teachers to develop a project "Model of Entrepreneurial Personality", which allows assessing themselves as an enterprising person on the date of installation for the development of entrepreneurial competence in high school students.

Project thinking, which is formed as a result of the activity approach, is based on responsibility and cooperation, needed not only by entrepreneurs but also by every person who seeks to be successful and contribute to the professional growth of teachers and competitiveness of graduates of the New Ukrainian School.

Conclusion. The analysis of awareness of Science teachers of the formation of entrepreneurial competency at the initial stage of the pedagogical experiment revealed a low and medium level, which contributed to the diversification of new methods of teacher training in the institutions of in-service teacher education.

Accordingly, a combination of traditional and interactive methods based on the principles of variability and interrelation was tested in experimental studies, disseminating European experience in the practice of in-service teacher education. It is 
this combination that contributes to the new activity approach to the educational process, which replaces translational education, which will ensure the formation of entrepreneurial competency and will not be limited to the reproduction of knowledge. By introducing interactive methods in in-service teacher education, it is possible to teach teachers to work on the development of students' competencies, rather than to chase the passage of educational topics. It is through these methods that a person can simulate life situations in the classroom and encourage students to think, communicate and act.

The effectiveness of these studies is confirmed by the conducted self-assessment of the skills of key competency "entrepreneurship" of teachers of natural sciences, which is presented in table 2 .

Thus, the updated methodological approaches to the organization of the educational process of the institutions of in-service teacher education contribute to the formation of the readiness of Science teachers to the development of entre-preneurial competency of high school students.

\section{References:}

Bacigalupo, M., Kampylis, P., Punie, Y., \& Van den Brande, G. (2016). EntreComp: The entrepreneurship competence framework. Luxembourg: Publication Office of the European Union. Retrieved from http://ipq.org.ua/upload/files/files/03_Novyny/2016.07.8-9_EntrComp/EntreCompFrame work\%20UKR.pdf

Bezrukova, B. C. (1996). Pedagogika. Proektionaja pedagogika. Uchebnoe posobie dlja inzhenernopedagogicheskih institutov $i$ industrial'no-pedagogi-cheskih tehnikumov [Pedagogy. Projective pedagogy. Textbook for engineering-pedagogical institutes and industrial-pedagogical technical schools]. Yekaterinburg: Business Book Publishing House.

Bobinskaya, E., Shiyan, R., \& Tovkalo, M. (2014). Lessons with an entrepreneurial background: educational materials. Warsaw: Owl.

Fitsula, M. M. (2006). Pedahohika vyshchoi shkoly. Pidruchnyk [Pedagogy of higher school: textbook]. Kyiv: Akademvydav.

Genisaretsky, O. I. (2001). Filosofija proektirovanija [Philosophy of Project making]. Retrieved from http://www.shkp.ru/lib/archive/second/2001-1/2.

Grishina, T. V. (2003). Osvitnia tekhnolohiia yak obiekt metodychnoi roboty [Educational technology as an object of methodical work]. Kharkiv: Osnova.

Matyash, N. V., \& Semenova, N.Z. (2000). Podgotovka budushhih uchitelej tehnologii $k$ obucheniju shkol'nikov proektnoj dejatel'nosti [Training of future teachers of technology for teaching schoolchildren project activities]. Bryansk: BGPU.

Nisimchuk, O. S., Padalka, O. S., \& Shpak, O. T. (2000). Suchasni pedahohichni tekhnolohii [Modern pedagogical technologies]. Kyiv: Prosvita.

Kagan, S., Zahn, G. L., Widaman, K. F., Schwarzwald J., \& Tyrrell G. (1985). Classroom Structural Bias. In: R. Slavin, S. Sharan, S. Kagan, R. Hertz-Lazarowitz, C. Webb, \& R. Schmuck (Eds.) Learning to Cooperate, Cooperating to Learn. Boston: Springer. DOI: 10.1007/978-1-4899-3650-9_11.

Kremen, V. G (2003). Systema osvity Ukrainy [The system of education in Ukraine]. In V. G. Kremen (Ed.) Nepererona profesiina osvita: filosofiia, pedahohichni paradyhmy, prohnoz: monohr. [Continuing professional education: philosophy, pedagogical paradigm forecast]. Kyiv: Naukova Dumka.

Pakhomova, N. (2005). Metod uchebnogo proekta v obrazovatel'nom uchrezhdenii [Method of educational project in an educational institution] (3rd ed.). Moscow: ARKTI.

Prokopenko, I. F., \& Evdokimov, V. I. (2006). Pedagogichni tekhnolohii: pidruchnyk [Pedagogical technologies: textbook] (2nd ed.). Kharkiv: Collehium. 